\title{
The Strategies to Supply Efficient Fire fighting Force in High-rise Building by NFPA 550 Guide to the Fire Safety Concepts Tree: Focusing on Automatic Fire Suppression
}

\author{
Seong-Ju Oh1), Ha-Sung Kong2)
}

\begin{abstract}
In this study we applied the 'NFPA 550 Guide to the Fire Safety Concepts Tree' to analyze the efficient supply of fire fighting force. We proposed to the strategies of efficient supply of fire fighting force to high story of high-rise buildings and focused on automatic fire suppression. The supply time of fire fighting force is secured by rapid fire detection: installation of infrared thermal image cameras as temperature sensor; installation of video image-based fire detectors and CCTV to see protection zone; transmission of fire information rapidly and diversification of fire alarm, such as indication of smartphones; securing resource waiting for stations by installing easy-to-destruct glass and lifts; and application to gliding and rescue techniques. The supply of fire fighting water is secured: using helicopters and rescue techniques; looping main pipes; installation of high-pressure pumps and water supply towers; and dual configuration of emergency generator and wiring.
\end{abstract}

Keywords: Guide to the Fire Safety Concept Tree, High-rise Building, Fire Fighting Force, Automatic Fire Suppression, Firefighter

\section{Introduction}

High-rise building refers to buildings with 50 stories or more than 200 meters in height

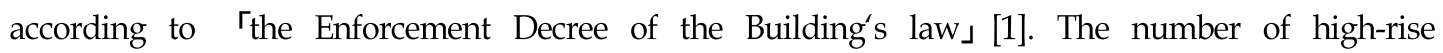
building in the country has been increasing every year; 89 in 2014, 92 in 2015, 107 in 2016 and 2017 and 107 in 2018[2]. The number of fires in high-rise buildings also continued to occur in 8 in 2016, 17 in 2017 and 15 in 2018[3]. High-rise buildings from vertical distribution, which makes it difficult to control smoke, to find fire stories from outside, to satisfy high pressure to supply firefighting water. Also, fire fighting action takes a lot of time due to difficulties in

Received(November 04, 2019), Review Result(1st: November 29, 2019, 2nd: January 07, 2020), Accepted(March 25, 2020)

1) (Chief) Rescue Team, 54968 Jeonbuk Fire Service, 225 hyojae-ro, Jeon-ju, Jeonbuk, Korea email: naguene5@korea.kr

2) (Professor, Corresponding Author) 55338 Dept. of Fire and Disaster Prevention, Woosuk Univ., 443 Samlae-ro, Wanju-gun, Jeonbuk, Korea email: 119wsu@naver.com 
The Strategies to Supply Efficient Fire fighting Force in High-rise Building by NFPA 550 Guide to the Fire Safety Concepts Tree Focusing on Automatic Fire Suppression

accessing the high floor[4]. "Automatically suppress fire" is automatically performed actions on a fire process in order to limit the growth of or extinguish the fire[5]. In light of the special nature of high-rise buildings, fire safety of high-rise buildings requires "automatically suppress fire" that automatically detects fires inside high-rise buildings and supplies sufficient fire fighting water. This is because automatic fire suppression can minimize human and physical damage and can make fire-fighting forces respond to fires quickly. There were previous studies about supply of fire-fighting forces. Kwon's[6] "A Study on the Evacuation and Fire Protection Facilities of Tall Buildings" was confined to building manager. Jung's[7] "A Study on Improving Fire and Evacuation Response of Tall Buildings" was restricted firefighting Equipment. Kim's[8] "A Study on the Design Plan for Securing Effectiveness of High-rise Building Fire Tactics" was focused on radio communication and air supply System. Kim's[9] "An Experimental Study on the Application of Connected Pipeline Equipment in Fires of Super-Buildings" was restricted firefighting water. Lee's[10] "A Study on Efficient Fire Suppression in High-rise Buildings" was confined to fire suppression. Yoo's[11] "Firefighters' on-site access in case of skyscraper" was focused on firefighter. However, a comprehensive study on the overall supply of firefighting force in high-rise buildings is hard to find. In particular, there is no studies to apply for the NFPA 550[12] Guide to the fire safety concepts Tree. Therefore, this study intended to suggest methods to supply firefighting force to high-rise buildings in order to solve the negative effects. We analyzed efficiency of firefighting force focusing on automatically fire suppression in order to limit the growth of or extinguish the fire by applying NFPA 550 Guide to the fire safety concepts Tree for fire safety in high-rise buildings.

\section{Theory of NFPA 550 Guide to the Fire Safety Concepts Tree}

The fire safety concepts tree theory in NFPA 550 provides comprehensive regulations on prevention of fire ignition, fire management of diminishing of fire growth and exposed management of protection of evacuees[13]. NFPA 550 uses communication channel of fire safety among designer, engineer, code maker and firemam. It applies fire the safety concepts analysis to general buildings, including high-rise buildings[14]. NFPA 550 defines the purpose of fire safety concepts tree theory as "fire safety". The structure of the fire safety tree consists largely of two categories: prevent fire ignition and manage fire impact. Fire prevention consists of matters related to thermal energy sources and fuel control. Fire impact management consists of fire management and evacuees management who want to reduce damage after fire. This structure is constructed by using the logic gates of "OR gate" and "AND gate" which show 
hierarchical relationships. The higher and lower classes are linked with either the "OR gate" or the "AND gate" and the higher classes display the output and the lower classes indicate the input. If the components of the lower layer are linked as "OR gate", the output will be displayed even if only one of the input elements of the lower layer is entered. On the other hand, if the components of the lower layer are connected by an "And gate" the all input elements of the lower layer must be entered to output results.

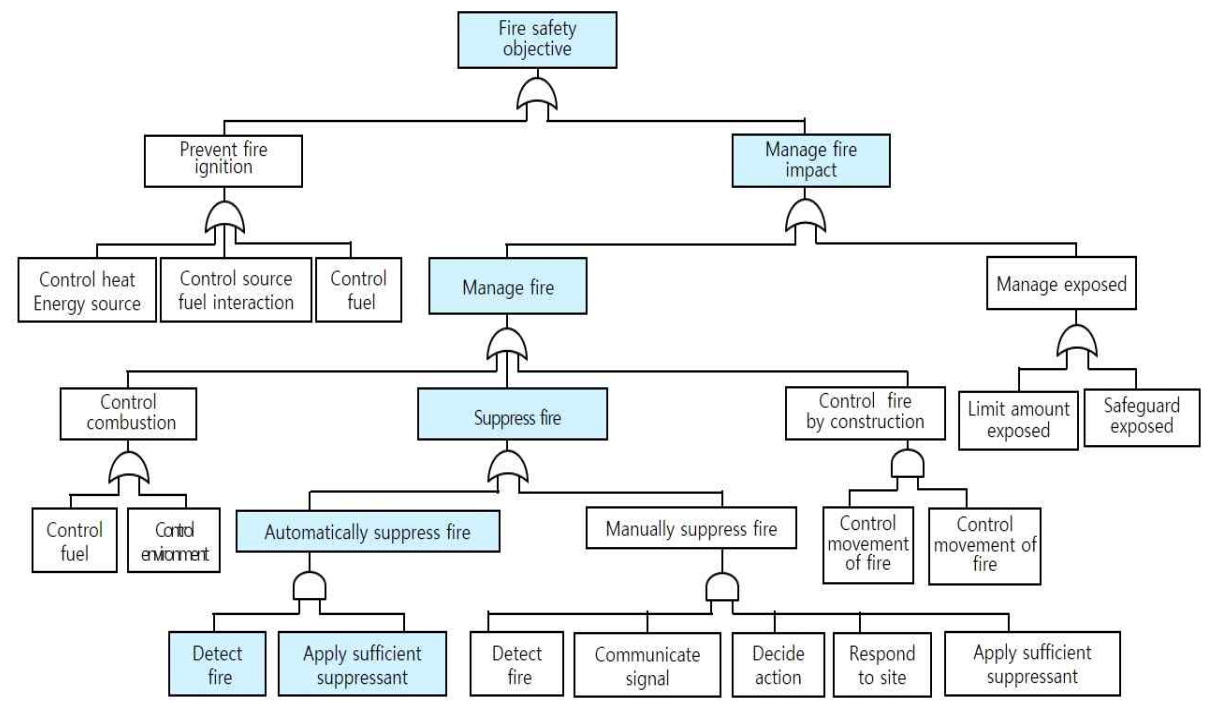

[Fig. 1] NFPA 550 Guide to the Fire Safety Concept Tree

[Fig. 1] gives an overview of the tree for fire safety referred to NFPA 550. Manage fire impact is connected to the "OR gate" between Manage fire and Manage exposed. and if either of the two is realized, the purpose of Manage fire impact is achieved. Manage fire can be achieved by one of the strategy of Control combustion, Suppress fire and Control fire by construction, because those three elements are connected to the "OR gate". We will focus on Automatically suppress fire in the field of the Suppress fire strategy among the three strategies of Control combustion, Suppress fire and Control fire by construction. If the Automatically suppress fire is carried out properly, the purpose of the Manage fire is achieved and the Fire safety objective, the top strategy of fire safety tree can be achieved as well. Therefore, I will suggest methods to supply firefighting force in high stories to apply to the Automatically suppress fire for fire safety of high-rise buildings. The Automatically suppress fire is composed of two strategies: Detect fire and Apply sufficient suppressant, so both strategies must be achieved to accomplish the Automatically suppress fire because those two elements are connected to the "AND gate". The Automatically suppress fire performs actions on a fire 
The Strategies to Supply Efficient Fire fighting Force in High-rise Building by NFPA 550 Guide to the Fire Safety Concepts Tree Focusing on Automatic Fire Suppression

process in order to limit the growth of or extinguish the fire automatically. It is to suppress fire to use fire facilities that detects fire and supplies sufficient fire extinguishing fluid to areas where fires have occurred in automatically. The Automatically suppress fire limits the growth of combustion in case of exceeding the fire intensity designed, and firefighting water shall be supplied in addition. "Detect fire" identifies the pressence of fire without reliance on human observation. This refers to the automatic identification of a fire by a fire detector, not by a person. "Apply sufficient suppressant" is automatically performing suppressive action in respond to automatic detection. Apply sufficient suppressant detects the fire automatically fire and engage in firefighting activities. When sufficient firefighting water is supplied to the fire floor of the high-rise buildings the fire is quickly suppressed and fire safety is achieved. The above is summarized in [Table 1].

[Table 1] The Input Elememts of Automatically Suppress Fire

\begin{tabular}{c|c}
\hline Division & Definition \\
\hline Detect fire & Detecting the presence of fire without reliance on human observation. \\
\hline $\begin{array}{c}\text { Apply sufficient } \\
\text { suppressant }\end{array}$ & Automatically performing suppressive action in respond to automatic detection \\
\hline
\end{tabular}

\section{Research Model and Analysis Standards}

The research model consists of a complete medition parameter as shown in [Fig. 2]. Automatic detections about accurate fire information have a positive effect on the analysis of efficiency in supply of firefighting force. An efficiency also is improved by supply of sufficient firefighting water. An alternative supply of firefighting force can be prepared according to the analysis of efficiency. So "automatically suppress the fire" is completed by supply of firefighting force. In addition, two input elements of "Detect fire" and "Apply sufficient suppressant" are promoted when firefighting force is supplied, so methods of apply firefighting force are refluxed.

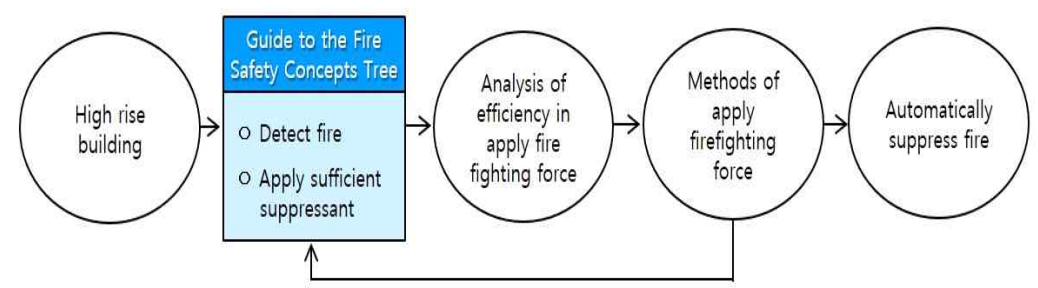

[Fig. 2] Research Model 
Detect fire reduces time of firefighting force supply by applying to rapid detection of the fire, determination of fire location and fire intensity, transmission of fire information, securing a resource station and suppression tactics. Apply sufficient suppressant is accomplished by water supply with a proper pressure. The pressure of firefighting water also is done by operation of pressurized water supply system and firefighting equipment. Therefore, the analysis standards were established as shown in [Table 2] to solve adverse functions depending on the structural characteristics of high-rise buildings.

[Table 2] Standards of Analysis

\begin{tabular}{|c|c|}
\hline Division & Analysis standard \\
\hline \multirow{5}{*}{ Detect fire } & Can you detect a fire quickly? \\
\hline & Can you know fire place and intensity of the fire quickly? \\
\hline & Can fire information be delivered smoothly? \\
\hline & Is it possible to secure a resource waiting station by controlling fire? \\
\hline & Can the suppression tactics be deployed according to intensity of the fire? \\
\hline \multirow{4}{*}{$\begin{array}{l}\text { Apply sufficient } \\
\text { suppressant }\end{array}$} & Can sufficient water for extinguishing fire be supplied to the fire floor? \\
\hline & Is the supply pressure of water for extinguishing fire appropriate? \\
\hline & Is it able to provide the power for the automatic fire extinguishing system smoothly? \\
\hline & Is it possible to supply the power to the fire floor for fire fighting equipment quickly? \\
\hline
\end{tabular}

\section{Analysis on the Efficiency of Fire-Fighting Force in High-rise Buildings}

\subsection{Detect Fire}

\subsubsection{Can You Detect a Fire Quickly?}

If the fire is detected and the fire is notified to the fire safety manager and 119 situation room, efficient firefighting force can be provided. In Usin Gold Sweat Fire (2010), it took about 26 minutes from the outbreak of fire to receipt of 119 reports[15]. One Meridian Plaza Fire (1991) was reported late by an outsider[16]. Delayed Fire detection, the Automatically suppress fire and the supply of fire fighting force are delayed.

\subsubsection{Can You Know Fire Place and Intensity of the Fire Quickly?}

If the fire location and intensity of the fire are known, the fire brigade can select dispatching 
The Strategies to Supply Efficient Fire fighting Force in High-rise Building by NFPA 550 Guide to the Fire Safety Concepts Tree Focusing on Automatic Fire Suppression

roots and supply firefighting force in accordance with the fire situation during automatically fire suppression. Unless smoke is emitted, it is difficult to identify fire layers from outside because high-rise buildings are without windows and vertical structure[17]. It is difficult to identify fire location and combustion situation as the space is closed horizontally[18].

\subsubsection{Can Fire Information be Delivered Smoothly?}

Fire information can be sent to automatic fire extinguishing facilities and 119 situation room when fire information is delivered smoothly from fire detectors to receivers. Even in the World Trade Center fire, the fire monitoring system was not activated due to the shutdown of the emergency operation control center[19]. Therefore, if the time to deliver fire information is longer, the time to supply automatically fire suppression and firefighting force is delayed.

\subsubsection{Is it Possible to Secure a Resource Waiting For Station by Controlling Fire?}

If the fire is controlled to secure the resource standby station, it can supply firefighting force continuously. It is only possible to secure resource standby station at the direct lower story of the fire floor by detecting fire quickly and supplying firefighting water with automatic water with automatic fire extinguishing facilities. SOP 223[20] stipulates that the resource standby office shall be installed on the direct lower level of the fire floor to manage fire-fighting equipment, such as personnel and lighting equipment.

\subsubsection{Is it Possible to Supply the Power to the Fire Floor for Firefighting Equipment Quickly?}

Rapid detection of fires and limiting combustion expansion can establish a rapid supply line of fire fighting force. The core of the suppression tactics should detect movements of fighters and firefighting equipment, and maintain a constant supply line[21]. The selection of fire fighting tactics is limited to the scale of possessing firefighting forces. Therefore, it should be selected the firefighting tactics according to the magnitude of firefighting forces.

\subsection{Apply Sufficient Suppressant}

\subsubsection{Can Sufficient Water for Extinguishing Fire be Supplied to the Fire Floor?}

A fire fighting water may be scarce if multiple sprinkler heads on the fire floor are opened or heads of sprinkler facilities on multiple floors are opened. Water sources have been depleted 
on Wooshin Goldsweet Fire (2010) and Smokud Tower Fire (1993) due to the opening of a number of sprinkler heads. Therefore, it is necessary to supply fire fighting water to supplement automatically fire suppression to limit growth of the fire.

\subsubsection{Is the Supply Pressure of Water for Extinguishing Fire Appropriate?}

A firefighting water supplied to high-rise buildings must be hold at adequate pressure for rapid automatically fire suppression. Firefighting water was not supplied due to low pressure when firefighting water was conveyed from a fire pump truck[22]. Therefore, suitable pressure is also required for fire fighting water.

\subsubsection{Is it Able to Provide the Power for the Automatic Fire Extinguishing System Smoothly?}

The pressurized water supply system should be operated swiftly to supply firewater automatically. The power supply was cut off because the emergency power supply failed to operate in the smokud Tower fire (1993)[23]. Therefore, the pressurized water system must be smoothly supplied with power for automatically fire suppression.

\subsubsection{Is the Power Supplied to the Fire Floor for Firefighting Equipments Quickly?}

Much firefighting equipment required to drive electric power. Unless power is supplied for firefighting equipment, that cannot be efficiently supplemented to automatic fire suppression. The supply of the power for the operation of the firefighting equipment improves efficiency of the supply of the fire fighting equipments, and makes up for a lack of automatically fire suppression because firefighting equipment that requires power in the resource standby station cannot be used without emergency power.

\section{Strategies to Supply Efficient Firefighting Force in High-rise Buildings}

\subsection{Detect Fire}

\subsubsection{Securing Time to Supply Firefighting Force to Install Infrared Thermal Image Camera} according to the Temperature Step by Step

Automatic fire suppression is automatically performing actions on a fire process in order to limit the growth of or extinguish the fire: to Detect fire automatically and supply fire fighting water. It is necessary to supplement supply firefighting water when the fire occurs in. Rapid fire detection can supplement automatic fire suppression even if it applies to small firefighting 
The Strategies to Supply Efficient Fire fighting Force in High-rise Building by NFPA 550 Guide to the Fire Safety Concepts Tree Focusing on Automatic Fire Suppression

force and water supply. The regulation stipulates that analog type fire detectors should be installed except for apartment buildings among high-rise buildings. On the other hand, it uses a infrared thermal image camera that detects the temperature and shows the internal situation on the screen to rescue the people because of thick smoke in the fire site. Therefore, it is necessary to make it mandatory for all high-rise buildings to install a fire detector based on analog methods and a infrared thermal image camera that can monitor the temperature in real time in order to detect the fire quickly. Since infrared thermal image cameras detect heat and display temperature as an image, it is efficient to use temperature sensors to detect temperature in the protection area in real time and to alert at operating temperature $\left(60^{\circ} \mathrm{C}\right)$ of heat detector in the fire shutter. Rapid fire detection and notification can give time to supply fire fighting force to the fire floor.

\subsubsection{Securing Time to Supply Firefighting Force to Know the Fire Location and Intensity with Infrared Thermal Image Cameras $\cdot$ Analogue Detectors $\cdot$ CCTV}

Lee[24] argued to install CCD fire image cameras and Son[25] presented video-based Fire detection using CCTV systems for visual detection of fire. Therefore, it is necessary to make it mandatory for high-rise buildings to install an address type analog fire detector. It is necessary to install a infrared thermal image camera. And it needs to link CCD fire image cameras and CCTV so as to quickly identify the location and intensity of the fire.

\subsubsection{Securing Time to Supply Firefighting Force by Diversifying Fire Alarm and Transmitting Fire Information through Indication of External Fire Floor}

Lee[26] proposed a system for notifying managers of fire occurrence by means of acoustic equipment, vibration and voice. It is necessary to make it mandatory for high-rise buildings to install an address type analog fire detector in order to transmit fire information to the administrator and to notify the fire by sound, vibration or voice using smartphones. And it is required to install display device or pilot light that can indicate the floor where the fire occurred on the outside of the high-rise buildings. It also strengthens the reliability of fire information transmission by installing electric wiring as a fire proof wire. A rapid transmission of fire information ensures the supply time of firefighting force as this.

\subsubsection{Supplication of Fire Fighting Force Supply base in Securing Resource Waiting Stations by Installing Easy-to-destruct Glass and Lifts}

A rapid Fire detection ensures time for the establishment of a resource waiting station on the 
direct lower floors of the fire story while the automatic fire extinguishing facility controls the fire. Yoo[27] inisisted that installing an entry window for firefighting purpose in the high-rise buildings allows firefighters to enter the building, and Kim[28] used the gondola outside the high-rise buildings for fire suppression. Therefore, it is required to install glass windows that can be easily destroyed, to do discrimination sign per some stories in order to secure resource waiting station from entering outside because emergency elevators inside is crowed by evacuees. In addition, it is necessary to make it mandatory for all high-rise buildings to install lifts or the gondola so as to enter under two floors of the fire story.

\subsubsection{Supplication of Firefighting Force by Applying to Crossing a River or Vertical Rescue Techniques}

Lee[29] argued that fire fighting tactics should be used by analyzing characteristics of fire and fire environment. "Rescue equipment operation and training standards"[30] stipulates the methods of crossing the river or horizontal rescue techniques to rescue the isolated person from flooding the river. When emergency elevators are not available, it is necessary to supplement automatic fire suppression by applying the methods of crossing the river, gliding and vertical rescue techniques to supply fire fighting force in the resource waiting for station. First, the crossing the river method is to enter with horizontal rescue techniques in adjacent buildings. The rope is spread from a nearby high-rise building's evacuation safety zone to command post with a rope gun or drone. And then the firefighter connects ropes between fired building and nearby buildings.

The fire fighting force can be supplied from the evacuation safety zone of adjacent high-rise buildings by the technique of the crossing the river through a connected rope[31]. Second, the gliding method is a technique for entering a high-rise building from the outside using a helicopter. If the two layers ladder is spread to front command post from the helicopter, the rope is connected from front command post to helicopter and the firefighter enters into high-rise buildings through a two layer ladder. So, the firefighter can quickly enter from the helicopter to front command post with gliding technique. Third, if a rope is spread to front command post from the helicopter to the front command post with a rope gun, the firefighter can quickly enter from the helicopter to front command post with gliding technique because the rope is connected front command post to helicopter[32]. Finally, the vertical rescue method is used to enter the front command post using an emergency hoistway of emergency elevators. It installs a triangular support on the hoistway of the front command post, connects the pulley, and lowers the rope through the hoistway. When the firefighter is joined to the lowered rope, 
The Strategies to Supply Efficient Fire fighting Force in High-rise Building by NFPA 550 Guide to the Fire Safety Concepts Tree Focusing on Automatic Fire Suppression

the firefighter at the front command post pulls up the rope to enter at the front command post.

\subsection{Apply Sufficient Suppressant}

\subsubsection{Supplication of Sufficient Firefighting Water to Use Helicopters and Adjacent Buildings}

Kim[33] proposed to supply firefighting water through mobile water tank, and fire pump using a connecting standpipe system from a fire truck. When water source is depleted, if it takes down the water tank and water pump on the roof with hoist of helicopter, then the water pump is put into the water tank, and then the generator is operated to supply fire fighting water to the rooftop water tank, the firefighting water is automatically supplied to the fire floor through the standpipe. Alternatively, the rope and fire hose is spread from a nearby building's evacuation safety zone to fired building with a rope gun or drone. If firefighter connects hose and standpipe or hydrant respectively, the firefighting water is automatically supplied to the fire floor through the standpipe or hydrant.

\subsubsection{Supplication of Firefighting Water with Adequate Pressure to Loop Main Pipes, to Install High-pressure Pumps and Water Supply Towers}

$\operatorname{Sin}[34]$ advocated the introduction of a high-pressure pump truck is capable of transmitting up to $400 \mathrm{~m}$ through the connecting standpipe to supplement automatically fire suppression by supplying fire fighting water in addition to the protection zone. First, it is necessary to install the high-pressure pump to connect the pipe of the waterworks fire extinguishing facility so as to supply fire fighting water automatically when water source is depleted or the automatic extinguishing facility is not operated. Second, it is necessary to install the loop of the main vertical pipes of two high-rise buildings in order to supply fire fighting water with adequate pressure automatically. Automatic valve is installed to looping pipe for control of fire fighting water, and then the valve is closed normally and automatically opened to provide fire fighting water with proper pressure. Finally, the "Fire Safety Standards for High-rise Buildings" are amended to ensure the reliability of the firefighting water supply in order to install water towers of equal to height in high-rise buildings. 


\subsubsection{Dual Configuration of Emergency Generator and Wiring to Improve Reliability of Pressurized Water Supply System}

The pressurized water system of the automatic fire extinguishing facility should be operated for supplying firefighting water automatically. It also stipulates that a self generator, a preliminary battery or electric storage should be installed with emergency power. Therefore, it is necessary to make it mandatory for all high-rise buildings to install dual self generators and dual wiring to ensure reliability of emergency power.

\subsubsection{Emergency Power Supply for Fire Equipment Operation using an Elevated Ladder Truck}

Even if fire equipment is supplied to the fire floor, fire equipment that requires driving power cannot be efficiently supplemented supply firefighting water unless power is supplied for driving. Firefighting equipment that requires power cannot be used in situations where emergency power is not supplied due to loss of power cables. The generator is arranged between the 11th and 18th floors of the high-rise buildings. If the generator output terminals are connected to the emergency outlet facility, the electric power is supplied automatically.

As above, [Table 3] summarizes the efficient method of supplying fire-fighting power to high-rise buildings.

[Table 3] Efficient Strategy Supply Firefighting Force to Follow Analysis of Fire-fighting Force

\begin{tabular}{|c|c|c|}
\hline $\mathrm{D}$ & nalysis of supply fire-fighting force & Efficient strategy supply fire-fighting force \\
\hline \multirow{5}{*}{ Detect fire } & Rapidly Fire detection & $\begin{array}{l}\text { Installation of analog type fire detectors, infrared } \\
\text { thermal image cameras as temperature sesors. }\end{array}$ \\
\hline & Knowing fire place and intensity & $\begin{array}{l}\text { Installation of video image-based fire detectors } \\
\text { and CCTV to see protection zone. }\end{array}$ \\
\hline & $\begin{array}{l}\text { Smoothly communication of fire } \\
\text { information }\end{array}$ & $\begin{array}{l}\text { Diversification of fire alarm, indication of external } \\
\text { fire floor and transmitting fire information. }\end{array}$ \\
\hline & $\begin{array}{llll}\begin{array}{l}\text { Securing a } \\
\text { station }\end{array} & \text { resource } & \text { waiting } \\
\end{array}$ & $\begin{array}{l}\text { Securing resource waiting for stations by } \\
\text { installing easy-to-destruct glass and lifts. }\end{array}$ \\
\hline & Suppression tatics for fire intensity & $\begin{array}{l}\text { Application of gliding, horizontal and vertical } \\
\text { rescue techniques. }\end{array}$ \\
\hline \multirow{4}{*}{$\begin{array}{c}\text { Apply } \\
\text { sufficient } \\
\text { suppressant }\end{array}$} & $\begin{array}{l}\begin{array}{l}\text { Sufficient supply of water for } \\
\text { extinguishing fire }\end{array} \\
\end{array}$ & $\begin{array}{l}\text { Sufficient firefighting water supply to use } \\
\text { helicopters and rescue techniques. }\end{array}$ \\
\hline & $\begin{array}{l}\text { Adequate pressure of water for } \\
\text { extinguishing fire Pressure }\end{array}$ & $\begin{array}{l}\text { Looping main pipes, install high-pressure pumps } \\
\text { and water supply towers. }\end{array}$ \\
\hline & $\begin{array}{l}\text { Power supply of pressurized } \\
\text { water supply system }\end{array}$ & $\begin{array}{l}\text { Dual configuration of emergency generator and } \\
\text { wiring. }\end{array}$ \\
\hline & $\begin{array}{l}\begin{array}{l}\text { Power supply for fire fighting } \\
\text { equipment }\end{array} \\
\end{array}$ & $\begin{array}{l}\text { Emergency power supply for fire equipment } \\
\text { using an high ladder truck and generator. }\end{array}$ \\
\hline
\end{tabular}


The Strategies to Supply Efficient Fire fighting Force in High-rise Building by NFPA 550 Guide to the Fire Safety Concepts Tree Focusing on Automatic Fire Suppression

\section{Conclusions}

In this study, we analyzed the efficiency to supply fire fighting force supply and suggested strategies to supply firefighting force in high-rise buildings by applying to "NFPA 550 Guide to the Fire Safety Concepts Tree". The supply time of fire fighting force is secured by fire detection as follows. First, it is to install infrared thermal image cameras as temperature sensor and analog type fire detectors. Second, there are need to install video image-based fire detectors and CCTV to see protection zone. Third, it is necessary to transmit fire information rapidly and to diversify fire alarm, such as indication of external fire floor and smartphones. Forth, we propose to secure resource waiting for stations by installing easy-to-destruct glass and lifts. Finally, there are effective methods to apply to gliding, horizontal and vertical rescue techniques. The supply of fire fighting water is secured by apply sufficient suppressant as follows. First, we insist that supply sufficient fire fighting water to use helicopters and rescue techniques. Second, it is necessary to make it mandatory for buildings to loop main pipes, and to install high-pressure pumps and water supply towers. Third, it is to install dual configuration of emergency generator and wiring. Finally, supply for emergency power using an high ladder truck and generator is demended.

\section{References}

[1] Buildings act, Article 2, The South Korean Ministry of legislation (2019), No.15.

[2] National Fire Department, National Fire Service Statistics Yearbook, National Fire Department, Sejong Special Self-Governing City, (2018), p.56.

[3] https://www.news1.kr/articles/?3123937/, Oct 15 (2017)

[4] J. Lee, A Study on Efficient Fire Suppression in High-rise Buildings, Kyonggi University, Graduate School of Construction Industry, Fire and Disaster Prevention, Master's Thesis, (2012), p.9.

[5] NFPA 550 Guid to the fire safety concepts tree, Article 3.3.4, (2017)

[6] D. P. Kwon, A Study on the Evacuation and Fire Protection Facilities of Tall Buildings, Kangwon National University, Graduate School of Industry, Fire \& Disaster Prevention, Master's Thesis, (2018), p.54.

[7] T. S. Jung, A Study on Improving Fire and Evacuation Response of Tall Buildings, Kwangwoon University, Graduate School of Environment, Disaster Safety Management Division, Master's Thesis, (2017), p.37.

[8] H. J. Kim, A Study on the Design Plan for Securing Effectiveness of High-rise Building Fire Tactics, University of Seoul, Graduate School of Urban Sciences, Disaster Prevention Engineering, Master's Thesis, 
(2017), p.100.

[9] E. J. Kim, An Experimental Study on the Application of Connected Pipeline Equipment in Fires of Super-Buildings, Kyonggi University, Graduate School of Construction Industry, Fire \& Disaster Prevention, Master's Thesis, (2014), p.53.

[10] J. Y. Lee, A Study on Efficient Fire Suppression in High-rise Buildings, Kyonggi University, Graduate School of Construction Industry, Fire and Disaster Prevention, Master's Thesis, (2012), p.41.

[11] J. H. Yoo, Firefighters' on-site access in case of skyscraper, Kyungil University, Graduate school, Fire \& Disaster Prevention, Ph.D Thesis, (2014), p.100.

[12] NFPA 550 Guid to the fire safety concepts tree, Article 4.5.1, (2017)

[13] https://bsbgroup.com/blog/fire-safety-masterclass-chapter-three-super-high-rise-buildings/, Mar 13 (2018)

[14] https://www.techstreet.com/standards/nfpa-fire-550?product_id=1938756/, Dec 01 (2018)

[15] H. C. Shin, A Study on the Fire Countermeasures of High-rise Buildings, Mokwon University, Graduate School of Industry, Master's Thesis, (2011), p.23.

[16] J. H. Yoo, Firefighters' on-site access in case of skyscraper, Kyungil University, Graduate school, Fire \& Disaster Prevention, Ph.D Thesis, (2014), p.33.

[17] H. C. Shin, A Study on the Fire Countermeasures of High-rise Buildings, Mokwon University, Graduate School of Industry, subject of study of firedepartment, Master's Thesis, (2011), p.13.

[18] T. S. Jung, A Study on Improving Fire and Evacuation Response of Tall Buildings, Kwangwoon University, Graduate School of Environment, Disaster Safety Management Division, Master's Thesis, (2017), p.37.

[19] H. J. Kim, A Study on the Design Plan for Securing Effectiveness of High-rise Building Fire Tactics, University of Seoul, Graduate School of Urban Sciences, Disaster Prevention Engineering, Master's Thesis, (2017), p.43.

[20] Disaster Site Standard Procedures, SOP223, Super Tall Building Fire Response Procedure, Jeollabuk-do Fire Department, (2018), p.57.

[21] K. Y. Kim, A Study on the Fire Safety Management Plan of Tall Buildings, Kwangwoon University, Service Management, Master's Thesis, (2012), p.43.

[22] H. J. Kim, A Study on the Design Plan for Securing Effectiveness of High-rise Building Fire Tactics, University of Seoul, Graduate School of Urban Sciences, Disaster Prevention Engineering, Master's Thesis, (2017), p.60.

[23] K. O. Kwon, Skyscraper Fire Cases and Lessons, Disaster Prevention Research, (2003), Vol.5, No.3, p.39.

[24] J. H Lee, A Study for Video Fire detector installation standards of CCD camera, Dept. of Fire \& Disaster Protection Engineering, Graduate School of Gachon University, Disaster Prevention Engineering, Master's Thesis, (2019), p.37.

[25] T. G. Son, Research of Video Based Real-Time Fire detection Algorithm Using GPU, University of Ulsan, Graduate School of Urban Sciences, Electric-Electron-Computer Engineering, Master's Thesis, (2015), p.2, 
The Strategies to Supply Efficient Fire fighting Force in High-rise Building by NFPA 550 Guide to the Fire Safety Concepts Tree Focusing on Automatic Fire Suppression

[26] H. G. Lee, Development of IoT-based Fire detector and mobile phone alarm system, Kangwon National University, Graduate School of Disaster Prevention, Disaster Prevention System, Master's Thesis, (2019), p.2.

[27] J. H. Yoo, Firefighters' on-site access in case of skyscraper, Kyungil University, Graduate school, Fire \& Disaster Prevention, Ph.D Thesis, (2014), p.96.

[28] M. S. Kim, Thestudy of extinguishing and prevention for fires on highbuildings, Graduate School of Public Administration Kyunggi University, Urban and localautonomy, Master's Thesis, (2013), pp.51-53.

[29] Y. I. Lee, A Study on the Improvement of Fire Fighting Tactics through Real Housing Fire Experiment, Kyunggee University, Urban Sciences, Disaster Prevention Engineering, Ph.D Thesis, (2019), pp.107-108.

[30] Rescue Equipment Operation and Training Standards, article 37, Korea Ministry of Government Legislation, (2016)

[31] https://news.joins.com/article/22544624/, JoongAng Ilbo, Apr 04 (2018)

[32] http://www.segye.com/newsView/20170209003722/, Segyeilbo, Sept 02 (2017)

[33] E. G. Kim, An Experimental Study on the Application of Connected Pipeline Equipment in Fires of Super-Buildings, Kyonggi University, Graduate School of Construction Industry, Fire \& Disaster Prevention, Master's Thesis, (2014), pp.41-42.

[34] H. C. Shin, A Study on the Fire Countermeasures of High-rise Buildings, Mokwon University, Graduate School of Industry, Master's Thesis, (2011), p.53. 